\title{
Zmiana społeczno-kulturowa a renesans sportu powszechnego w Polsce
}

\author{
Abstract \\ Social and cultural change in Poland and the revival \\ of universally accessible sport
}

This paper aims to highlight the reasons behind the revival of universally accessible sport among the Polish public from the perspective of the social and cultural change that has taken place in Poland. The goal is to substantiate this revival through social sciences and theories of social change that dominate such sciences. The analysis below identifies two groups of key factors that have stimulated the public's participation in universally accessible sport. The first group are social factors such as a surge in the number of people with higher education, the statistically increased affluence of Polish people, a higher percentage of white-collar workers, migration from rural to urban areas, and improved access to sports equipment and facilities. Factors in the other group are of cultural nature and include the following: the prevalence of aesthetic and hedonistic models of physical culture in society, the increased prestige and significance of sport consumption in the public's consumption of culture, and the activation of informal social control in society, leading to positive sanctions for engaging in sporting activity and negative sanctions for refusing to do so. This group of factors also includes a growing number of people who, guided by rational and empirical truths, cease to interpret the success of others through the categories of theological or biological determinism and instead, they opt to act individually and together with others, also when it comes to health and fitness. Finally, a growing percentage of people accept the truth that good health primarily depends on prevention and lifestyle rather than hospital treatment and medication.

Analizując sport w długiej perspektywie historycznej, dochodzimy do przekonania, że zjawiska i procesy występujące w społeczeństwie stają się udziałem 
samego sportu. Oznacza to, że sport zawiera w sobie te elementy, które są charakterystyczne dla społeczeństwa i jego kultury. Jest emanacją tegoż społeczeństwa i tej kultury. Za ewolucjonistami, sięgając wstecz dziejów ludzkości, możemy wyodrębnić podstawowe typy społeczeństw, takie jak zbieracko-myśliwskie, kopieniackie, rolnicze i przemysłowe.

Rezygnując z poszukiwania zależności między społeczeństwem a sportem powszechnym w dalekiej perspektywie historycznej, przyjmując zaś socjologiczny punkt widzenia, ograniczymy się wyłącznie do dychotomicznego podziału na społeczeństwa tradycyjne i społeczeństwa przemysłowe, które są też nazywane nowoczesnymi czy industrialnymi. Szczególną uwagę skierujemy przy tym na społeczeństwo polskie, w którym w ostatnim 25-leciu zaszły głębokie zmiany we wszystkich dziedzinach i sferach życia. Ukażemy zmiany w rodzimym sporcie powszechnym, jakie dokonały się w ostatnich latach. Postaramy się także odpowiedzieć na pytanie, jakie czynniki miały decydujący wpływ na obecny stan rzeczy w sporcie powszechnym i dlaczego ten sport jest taki, jaki jest. Towarzyszyć nam będzie perspektywa nauk społecznych, co oznacza, że przyczyn zmian zachodzących w sporcie powszechnym będziemy poszukiwali w społeczeństwie i jego kulturze.

Do analizy wykorzystamy podstawowe teorie zmian społecznych, które pozwolą nam na opisanie oraz wyjaśnienie zachodzących w sporcie powszechnym zjawisk i procesów. Sięgniemy do teorii ewolucjonistycznej, teorii cykli społecznych, Marksowskiego materializmu historycznego, ale także teorii powstałej pod koniec minionego wieku, a mianowicie do teorii podmiotowości i stawania się społeczeństwa (Griswold 2012). Niejako pomocniczo zostaną również zastosowane dwie główne teorie społeczne: funkcjonalizm strukturalny oraz interakcjonizm społeczny.

\section{Cztery teorie zmiany społeczno-kulturowej}

Twórcami klasycznego ewolucjonizmu w socjologii są August Comte oraz Herbert Spencer. Teoria ta powstała z inspiracji oświeceniowego intelektualnego zaczynu na drodze poznania naukowego, charakterystycznego dla nauk przyrodniczych. Poszukuje prawidłowości ładu, sensu i porządku społecznego. W teorii tej społeczeństwo jest traktowane jak organizm ludzki, który na drodze progresywizmu nieustannie zmierza do coraz bardziej doskonałych stanów. Charakterystyczną cechą tego rozwoju społecznego jest z jednej strony różnicowanie się struktur i funkcji poszczególnych elementów, z drugiej natomiast coraz większe i doskonalsze zdolności adaptacyjne. Piotr Sztompka wskazuje na sześć ważnych przesłanek właściwych dla omawianej teorii. Pierwszą jest determinizm, który polega na uwarunkowaniu kolejnych etapów rozwoju przez wcześniejsze fazy i stadia. Drugą jest fatalizm, wedle którego proces ewolucji jest konieczny, nieuchronny i nieodwracalny. Jednostki i zbiorowości ludzkie nie mają jakiegokolwiek wpływu ani na jego kierunek, ani na dynamikę. Trzecią jest finalizm, który polega na zmierzaniu procesu do pewnego stanu końcowego. Czwartą jest 
progresywizm, przejawiający się w osiąganiu przez ewolucję coraz wyższych stadiów rozwoju, aż do osiągnięcia absolutnej realizacji dobra i szczęścia. Piątą jest uniformizm, który oznacza, że proces ewolucji nie dotyczy wybranego społeczeństwa, ale społeczeństwa jako całości, społeczeństwa globalnego. Szóstą jest jednoliniowość, która polega na tym, że ewolucja przebiega na jednej drodze i przechodzi przez wszystkie fazy i stadia, co wskazuje, że żadne społeczeństwo nie może ominąć lub przeskoczyć kolejnych etapów (Sztompka 2005, s. 493-494).

Z omawianej koncepcji ewolucjonizmu narodziły się teoria modernizacji oraz teoria społeczeństwa postindustrialnego. Pierwsza z nich tym różni się od klasycznego pierwowzoru, że modernizacja jest procesem zamierzonym i stymulowanym z zewnątrz. Innymi słowy, polega na tym, że centrum, gdzie znajdują się wzorce nowoczesności (chodzi o kraje tzw. Zachodu), rozprzestrzenia się do krajów peryferyjnych, znajdujących się na niższym etapie rozwoju. Modernizacja polega na zbliżaniu się w sposób zamierzony i celowy społeczeństw zapóźnionych w rozwoju do społeczeństw uznanych za model nowoczesności. Druga koncentruje uwagę na przewidywaniu i prognozowaniu przyszłości na podstawie pewnych niezmiennych cech ewolucji, takich jak konieczność, prawidłowość i nieodwracalność. Głosi, że przez prostą ekstrapolację konkretnych tendencji można określić wyłonienie się rozwiniętego społeczeństwa przemysłowego. W ramach tej teorii Daniel Bell wyodrębnił pojęcie społeczeństwa postindustrialnego. W swej koncepcji dzieli historię rozwoju ludzkości na trzy fazy: preindustrialną, industrialną i postindustrialną (Bell 1976). Na gruncie teorii Bella rozwija swą koncepcję megatrendów John Naisbitt, który za fundamentalne uważa pojęcie globalizacji. Globalne są gospodarka, rynek ekonomiczny, finansowy i podział pracy, komunikacja, turystyka, środki masowego przekazu, kultura, sztuka, rozrywka i informacja (Naisbitt 1982).

Teoria cykli społecznych została skonstruowana przez Vilfreda Pareta i przedstawiona w Traktacie o socjologii ogólnej (Pareto 1994). W jego koncepcji system społeczny nieustannie się zmienia. Historia toczy się w cyklicznym rytmie i przechodzi od równowagi poprzez destabilizację i załamanie się równowagi do ponownej równowagi itd. Teraźniejszość nie stanowi kulminacji, lecz jedynie przejściowy etap procesu. Dlatego też proces ten nie ma kierunkowości i nie dokonuje się w nim dziejowy postęp. W każdej fazie procesu o jego przebiegu decydują dominujące elity, a zwłaszcza elity rządzące. Badacz wyodrębnia elity dwojakiego rodzaju: lisów i Iwów. Charakterystycznymi cechami elity lisów są: innowacyjność, przedsiębiorczość, ekspansywność, zdolność do podejmowania ryzyka i pasja działania. Elity Iwów charakteryzują się konserwatyzmem, ostrożnością, tradycjonalizmem, kultem stabilności i ciągłości. W socjologii współczesnej niezwykle ważną teorię cykliczną sformułował amerykański intelektualista Pitirim Sorokin. Według niego świat społeczny konstytuują pełne systemy społeczno-kulturowe, które są podwójnie wewnętrznie zintegrowane: przyczynowo-funkcjonalnie, poprzez interakcje, podział pracy itp. oraz kulturowo, logicznie i znaczeniowo, poprzez analogię, wspólnotę stylu itp. Głównym składnikiem każdego systemu społeczno-kulturowego jest mentalność kulturowa, która ma wpływ na ujmowanie świata, określa hierarchię wartości oraz kryteria prawdy. I to ona determinuje 
kształt wszystkich innych składników. Sorokin wyróżnia dwa antynomiczne typy mentalności kulturowej: ideacyjny i zmysłowy. Pierwszy z nich zakłada, że świat jest wieczny, ma istotę duchową, jest niedostępny poznaniu zmysłowemu, a postęp polega na opanowaniu instynktów i popędów. Drugi przyjmuje, że świat jest materialny, najważniejsze są potrzeby fizyczne, a postęp polega na opanowaniu otoczenia i uzyskaniu jak najwięcej przyjemności i szczęścia. Historia społeczeństwa to powtarzalne zmiany mentalności kulturowej: od ideacyjnej poprzez idealistyczną do zmysłowej i tak dalej. Bieg historii to cykliczne przypływy i odpływy skrajnych stadiów mentalności kulturowej (Sorokin 1937).

Marksowski materializm historyczny swe założenia opiera na filozofii dialektycznej Georga Wilhelma Hegla. Koncepcja ta zakłada, że historią kierują żelazne prawidłowości, na wzór prawidłowości w przyrodzie. Polega na kierunkowym i nieodwracalnym przechodzeniu na drodze czasowego załamania (rewolucji społecznej) od jednych do kolejnych formacji społeczno-ekonomicznych, których zwieńczeniem jest komunizm. Mechanizm rozwoju jest immanentny oraz endogenny i wynika ze stale obecnych napięć, sprzeczności i konfliktów społecznych. Podstawowym kryterium konfliktów w kapitalizmie jest podział na klasy, które mają różny stosunek do środków produkcji. Jedni (burżuazja, kapitaliści) posiadają środki produkcji i czerpią ogromne zyski, drudzy (klasa robotnicza, proletariat) tych środków nie posiadają i są wykorzystywani przez tych pierwszych. Uzyskanie przez klasę robotniczą świadomości klasowej prowadzi do konfliktu klasowego i rewolucji. W Marksowskim mechanizmie dziejów formacją finalną jest społeczeństwo komunistyczne, w którym nie ma walki klasowej i alienacji, jest to, jak mówił Marks, „skok z królestwa konieczności do królestwa wolności” (Sztompka 2005, s. 517-524).

Teoria podmiotowości i stawania się społeczeństwa powstała pod koniec XX wieku jako odpowiedź na potrzebę nowej koncepcji zmian społecznych i historycznych. Nazywana jest też, dzięki Jeffreyowi Alexandrowi, „nowym ruchem teoretycznym" (Alexander 1988, s. 77-102). Teoria ta powstała - czy jest konstytuowana - w ramach dwóch nurtów, które ujmują społeczeństwo jako dynamiczny proces. Ludzie poprzez swoje działania kreują i reprodukują własną egzystencję, natomiast struktury społeczne są czynnikami hamującymi lub wspierającymi dalszą aktywność. Świat społeczny postrzegany jest jako rzeczywistość, na którą mają wpływ zarówno czynniki historyczne, jak i podmiotowe (Sztompka 1991). $Z$ jednej strony jest to teoria historyczna, której sztandarowymi przedstawicielami są tacy intelektualiści jak: Norbert Elias, Charles Tilly, Theda Skocpol, Michael Mann, z drugiej natomiast teoria podmiotowości, której reprezentantami są: Walter F. Buckley, Alain Touraine, Anthony Giddens, a także Piotr Sztompka.

Pierwsza z teorii, historyczna, zakłada, że świat społeczny nie jest stały, ale dynamiczny i nieustannie stający się. Społeczeństwo staje się przez zdarzenia. Zmiana społeczna w świetle tej teorii polega na zbieganiu, krzyżowaniu i ścieraniu się wielu tendencji i procesów. Społeczeństwo stanowi płynną siatkę stosunków społecznych, a zmiana wyłania się za każdym razem jako skumulowany rezultat etapów poprzedzających oraz zalążek procesów w przyszłości. Czynnikami sprawczymi zmiany społecznej są indywidualne i zbiorowe podmioty społeczne 
i ich działania. Zatem ludzie tworzą swoje społeczeństwo i historię w taki sposób, że poprzednie struktury społeczne determinują aktualne, a aktualne, zmieniane przez pokolenia, determinują struktury przyszłe. Druga teoria, podmiotowości, oparta jest na kilku założeniach ontologicznych. Społeczeństwo to płynna, nieustannie zmieniająca się rzeczywistość. Źródłem owej zmienności są indywidualni i zbiorowi członkowie tegoż społeczeństwa, ich sprawstwo i ich aktywność. Zmiana i jej szybkość są wypadkową ścierania się różnorodnych pluralistycznych sił i interesów. Każde działanie jest warunkowane (determinowane) strukturami zastanymi i struktury te kształtuje (determinuje).

Teoria stawania się społeczeństwa to próba wykorzystania założeń zarówno współczynnika historycznego, jak i podmiotowego. Każdy fakt społeczny w świetle tej teorii jest w konsekwencji efektem spójności czynnika jednostkowego i strukturalnego, wycinkiem pola jednostkowo-strukturalnego. Pole to jest w nieustannym ruchu, zmienia się i jest procesem. Elementarnym składnikiem społeczeństwa są zdarzenia społeczne. Są one rozumiane jako każde zdarzenie, zaczynając np. od wstania z łóżka, a na podejmowaniu ważnych decyzji zawodowych kończąc. Wszystko toczy się w ramach struktury społecznej i ma charakter w pełni dynamiczny oraz procesowy. Podmiotowość jest rozumiana jako szczególna właściwość społeczeństwa, która wyraża się w zdolności do społeczno-historycznej praxis. Innymi słowy, podmiotowość to zdolność społeczeństwa do przekształcania się. Jest to szczególna wypadkowa zdolności jednostek i zbiorowości, potencjalności struktur społecznych do powodowania przemiany. Podmiotowość społeczeństwa nie zapewnia sama z siebie transformacji, ale może przebiegać od społeczeństwa pasywnego do społeczeństwa aktywnego, pokonującego bariery i nieustannie budującego nową rzeczywistość (Sztompka 2002, s. 232-238).

\section{Społeczne uwarunkowania zmian w sporcie powszechnym}

Społeczeństwo polskie jest społeczeństwem nowoczesnym (modern society), w schyłkowej fazie rozwoju z tendencją przekształcania się w społeczeństwo ponowoczesne, co oznacza, że spełnia wszystkie kryteria charakterystyczne dla tego typu zbiorowości, takie jak: mechanizacja produkcji, zwiększenie zapotrzebowania na wykwalifikowanych pracowników, wzrost znaczenia nauki, utrata dotychczasowego autorytetu religii, nasilenie procesu urbanizacji, dominacja racjonalności itp., ale jednocześnie dominacja konsumpcjonizmu, hedonizmu, wszechobecność nowoczesnych technologii informatycznych, przesunięcie pracowników ze sfery produkcji do sfery usług, zwiększenie ryzyka dla jednostek i zbiorowości (Szczepański 1992). Społeczeństwo polskie posiada więc wszystkie cechy charakterystyczne dla społeczeństw zachodnich, ale też się od nich różni, jako że posiada doświadczenia systemu totalitarnego nazywanego socjalizmem, czyli ma za sobą drogę, której nie pokonywały społeczeństwa zachodnie. Przez to też nie ma wykształconych i ugruntowanych wzorów kulturowych, w tym wzorów konsumpcji sportowej. Ponadto poziom rozwoju społeczeństwa jest niższy 
niż w przypadku interesujących nas społeczeństw zachodnich (Bennett, Savage, Silva 2010).

Niezależnie od stwierdzonych różnic występujące w naszym społeczeństwie zjawiska i procesy sprzyjają zmianom świadomości i zachowań jego członków. Wynika to z tego, że przenikają doń ze społeczeństw zachodnich sprawdzone wzory życia i gospodarowania zasobami społecznymi. Świadomość potrzeby uczestnictwa w sporcie wynika z lepszego wykształcenia obywateli. Wśród krajów Unii Europejskiej Polska należy do liderów pod względem odsetka osób z wyższym wykształceniem. Udział osób w przedziale wiekowym 30-34 lata mogących pochwalić się dyplomem wyższej uczelni w Unii Europejskiej wyniósł w 2012 roku $36 \%$, natomiast Polska z wynikiem ponad $39 \%$ uplasowała się powyżej unijnej średniej. Warto wiedzieć, że ćwierć wieku temu odsetek ten w Polsce nie przekraczał 10\% (Wyższe wykształcenie Polaków... 2013).

Kolejnym czynnikiem mającym wpływ na uczestnictwo w sporcie powszechnym jest statystycznie wyższy poziom zamożności (Statistical Yearbook of the Republic of Poland 2012). Produkt krajowy brutto (per capita na głowę) w Polsce, jeden z najczęściej stosowanych na świecie wskaźników zamożności obywateli danego kraju, w 2012 roku podwoił się w stosunku do roku 1989. Obecnie zajmujemy czwarte miejsce od końca w rankingu zamożności społeczeństw UE, ale jednocześnie Polska jako jedyny kraj postkomunistyczny zanotowała taki wzrost (Eurostat: Polski PKB na głowę... 2014). Wymienione czynniki, a zwłaszcza zwiększony odsetek osób legitymujących się wyższym wykształceniem, spowodowały, że wzrosła rola racjonalnego myślenia charakterystycznego dla nauki i środowiska akademickiego.

Struktura zamieszkania według podziału na miasto i wieś również ma znaczący wpływ na uczestnictwo w sporcie. Wynika to nie tylko z trudniejszego dostępu do infrastruktury sportowej mieszkańców wsi, gorszego wykształcenia, mniejszej zamożności, gorszego stanu zdrowia, ale także z odmienności wzorów kulturowych na wsi oraz z tego, że „wieś sama w sobie jest upośledzająca”. W ostatnich dziesięcioleciach nastąpiła znaczna zmiana struktury zamieszkania, a mianowicie znaczący odsetek mieszkańców wsi migrował do miast. Jeśli w 1921 roku na wsi mieszkało ponad 75\% społeczeństwa, to w 2010 roku odsetek ten zmniejszył się do prawie 38\% (Polska. Wybrane dane statystyczne 2014). Zmiana w strukturze zamieszkania spowodowała, że większy odsetek ludności Polski realizuje wzory aktywności fizycznej w sposób charakterystyczny dla ludności miejskiej, tj. wykazuje większą aktywność w zakresie uczestnictwa w sporcie. Dodać do tego należy, że miejskie wzory uczestnictwa w sporcie z wielką dynamiką przenikają do małych miast i na wieś. Potwierdzają to ogólnopolskie badania internetowe przeprowadzone na celowo-losowej próbie ponad 67 tysięcy biegaczy. Wynika z nich, że w ostatnim, tj. 2014 roku, najwięcej przybyło biegających z małych miast i ze wsi, w tym kobiet (Polska Biega 2014).

Niezwykle istotną tendencją mającą wpływ na uczestnictwo społeczeństwa polskiego w sporcie powszechnym jest przesuwanie się ogromnej rzeszy pracowników fizycznych (niebieskich kołnierzyków) do tzw. zawodów inteligenckich (białych kołnierzyków). Powstaje nowy rodzaj społeczeństwa, które nazywane 
bywa społeczeństwem postindustrialnym, społeczeństwem informacyjnym, społeczeństwem konsumpcyjnym czy społeczeństwem opartym na wiedzy (Giddens 2006, s. 394-441). W gospodarce opartej na wiedzy przeważający odsetek zatrudnionych nie uczestniczy w procesie produkcji i dystrybucji dóbr materialnych, ale zajmuje się projektowaniem, przygotowaniem strategii rozwoju, marketingiem, dystrybucją i świadczeniem usług. Sytuacja taka powoduje, że większość społeczeństwa wykonuje tzw. prace umysłowe i w naturalny sposób odczuwa potrzebę aktywnego spędzania czasu wolnego, w tym uczestnictwa w sporcie. Na przeciwległym biegunie znajduje się malejący odsetek pracowników fizycznych, dla których najlepszą formą wypoczynku jest wypoczynek bierny, niewymagający wysiłku fizycznego. Tym samym zmiana struktury zatrudnienia sprzyja większemu zainteresowaniu kulturą fizyczną i większemu uczestnictwu w sporcie (Uczestnictwo Polaków w sporcie i rekreacji ruchowej w 2012 r.).

Skumulowanym czynnikiem mającym wpływ na uczestnictwo Polaków w aktywności sportowej jest jakość życia (Quality of Life). Jakość życia, według tygodnika „Economist Intelligence Unit”, ocenia się za pomocą następujących parametrów i mierników: sytuacja materialna, zdrowie, stabilność polityczna i bezpieczeństwo, życie rodzinne, życie wspólnotowe, klimat i geografia, bezpieczeństwo zatrudnienia, wolność polityczna, równość płci. Przykładowo badanie jakości życia mieszkańców Warszawy, wykonane przez spółkę Millward Brown S.A. na 7 200-osobowej, losowej, reprezentatywnej próbie mieszkańców w okresie od października do grudnia 2013 roku, wykazało, że odsetek osób zadowolonych z jakości życia waha się od pięćdziesięciu kilku do około siedemdziesięciu procent w poszczególnych wskaźnikach. Tak wysoki odsetek zadowolonych z jakości życia nie tylko dobrze świadczy o dokonujących się zmianach w Warszawie, ale także jest okolicznością bardzo sprzyjającą podejmowaniu decyzji o uczestnictwie w aktywności sportowej (Halicki 2014). Taki stan rzeczy potwierdzają wyniki wcześniejszych badań prowadzonych przez Janusza Czapińskiego i Tomasza Panka w ramach projektu Diagnoza społeczna 2013. W badaniach wzięło udział 26 tysięcy Polaków. Wynika z nich, że optymizm Polaków systematycznie wzrasta. Zadowolenie z życia zadeklarowało ponad $80 \%$ badanych. Taki obraz, zdaniem J. Czapińskiego, jest „najbardziej podnoszący na duchu”. Wyniki te potwierdzane są co kwartał przez badania Eurobarometru, z których wynika, że społeczeństwo polskie wypada konsekwentnie jako najbardziej optymistyczne w Unii Europejskiej (Czapiński, Panek 2013).

$Z$ jeszcze innych badań zawartych w raporcie Fundacji Bertelsmanna, a dotyczących poziomu sprawiedliwości społecznej, wynika, że Polska pod tym względem znajduje się na 16. miejscu, nieco poniżej średniej europejskiej (najlepiej wypadły takie kraje jak: Szwecja, Finlandia, Dania i Holandia). Jednak w Polsce występuje największa dynamika poprawy sprawiedliwości społecznej. W 2008 roku byliśmy na ostatnim miejscu, dzisiaj jesteśmy w środku stawki. Taki skok nie udał się żadnemu krajowi regionu. Widać to najwyraźniej po spadku zagrożenia biedą. W ciągu ostatnich siedmiu lat obniżyło się ono z 33 do $25 \%$. Jesteśmy liderem w naszym regionie jeśli chodzi o dostęp do edukacji. Pochodzenie społeczne polskich uczniów nie jest przeszkodą w zdobyciu wykształcenia. Polska pod tym 
względem charakteryzuje się największą ruchliwością społeczną wśród krajów Unii. W raporcie czytamy, że utrwala się podział Unii na zamożną i stabilną Północ i nieradzące sobie z problemami Południe. Przy czym Polska została zakwalifikowana do zamożnej i stabilnej Północy (Wieliński, Matusiak 2014, s. 1, 16-17).

Wymienione zjawiska i procesy społeczne powodują, że wzrasta świadomość potrzeby uczestnictwa w sporcie coraz większego odsetka członków naszego społeczeństwa, ale zwiększa się też odsetek jednostek uczestniczących w praktyce społecznej w tym zakresie. Taki stan rzeczy potwierdzają zarówno wyniki badań empirycznych (Uczestnictwo Polaków w sporcie i rekreacji ruchowej w $2012 r$. i inne prowadzone na niereprezentatywnych zbiorowościach), jak i codzienna obserwacja życia społecznego. Mówimy tu o potężnej rzeszy Polaków jeżdżących na rowerach, łyżworolkach, biegających w parkach i na obszarach zielonych, grających na orlikach, przewożących na dachach samochodów sprzęt narciarski czy do uprawiania windsurfingu. Coraz chętniej przedstawiciele naszego społeczeństwa biorą udział w różnorodnych piknikach, festynach i innych imprezach sportowo-rekreacyjnych (CBOS 2008, 2010, 2012, 2013). Organizowane są liczne imprezy biegowe, których popularność stale rośnie. W Maratonie Warszawskim w 2013 roku wystartowała rekordowa liczba około 10 tysięcy uczestników, a na trasę przyszła też rekordowa liczba kibiców.

Znaczący wzrost frekwencji zauważalny jest niemal we wszystkich otwartych imprezach biegowych. Dotyczy to przede wszystkim zawodów maratońskich (np. maraton w Krakowie ukończyło w 2013 r. 4415 osób, w 2008 r. - 1360, w Poznaniu w 2013 r. - 5678, w 2008 r. - 2640, w Dębnie w 2014 r. - 2074, w 2008 r. 713). Rosnącą popularnością cieszą się biegi na krótszych dystansach. Przykładowo półmaraton w Warszawie w 2014 r. ukończyło 11149 osób, w 2008 - 2371. W wiosennym maratonie w Warszawie w 2014 r. wzięło udział 31688 biegaczy (MaratonyPolskie.pl 2014). Skutkiem wzrostu zainteresowania potencjalnych uczestników jest organizacja nowych zawodów. W Festiwalu Biegowym w Krynicy w 2013 roku wzięło udział 8 tysięcy biegaczy, natomiast w $2012-4$ tysiące (Tycner 2014)1. W najbardziej prestiżowej imprezie w narciarstwie biegowym zaś, czyli w Biegu Piastów, w 2014 roku wzięło udział 6 tysięcy biegaczy, natomiast w 1976 r. - 531 (Męka 2014, s. 182).

Nie oznacza to jednak, że uczestnictwo w sporcie powszechnym naszego społeczeństwa jest na miarę potrzeb oraz oczekiwań. Nowoczesne społeczeństwa europejskie, i nie tylko, mają w tym zakresie dużo większe osiągnięcia. Dotyczy to przede wszystkim takich krajów, jak Szwecja, Norwegia, Finlandia, Dania, Niemcy, Francja, Holandia, Belgia itd. Przyczyną takiego stanu rzeczy jest wyższy poziom rozwoju cywilizacyjnego tych społeczeństw (Dimitrov, Helmenstein, Kleissner, Moser, Schindler 2006).

1 Według Zygmunta Berdychowskiego (organizatora Festiwalu Biegowego w Krynicy) w biegach masowych w Polsce może uczestniczyć od 200 do 300 tysięcy osób. 


\section{Kulturowe uwarunkowania zmian w sporcie powszechnym}

Niezwykle ważną kwestią pomocną w wyjaśnianiu tendencji w zakresie uczestnictwa w sporcie powszechnym jest dominacja w społeczeństwie określonych elementów kultury. Chodzi tu przede wszystkim o dominujące idee, wartości, normy, wzory zachowań, które często są konsekwencją pewnej tradycji i panujących w danym kraju obyczajów. W czasach Tomasza Hopfera, wybitnego dziennikarza sportowego, który jako pierwszy na tak dużą skalę, z wykorzystaniem telewizji i innych środków technologicznych kultury masowej, podjął dzieło upowszechnienia biegania w społeczeństwie polskim, bieganie było traktowane przez większość jego członków jako nieuprawniona ekstrawagancja, fanaberia, niedostosowanie do utrwalonego kulturowego porządku, a niekiedy jako dewiacja. Biegających traktowano jak dziwaków, zdarzało się, że byli wyśmiewani i obrażani, a nawet, szczuci psami².

Charakterystyczną cechą społeczeństwa polskiego jest przywiązanie do tradycyjnego katolickiego systemu norm i wartości, który zachęca wiernych do kultywowania wartości duchowych i intelektualnych, kosztem dbałości o rozwój fizyczny, sprawnościowy i zdrowotny. Tradycja ta, sącząca się dzisiaj niezwykle cienkim strumieniem w samym nauczaniu Kościoła, obecna jest w świadomości i zachowaniach znaczącej części wiernych, zwłaszcza tych słabo wykształconych i mieszkających na wsi. Chodzi mianowicie o to, że do świadomości znaczącego odsetka członków Kościoła hierarchicznego i wiernych świeckich nie może się przebić nowoczesne nauczanie posoborowe (Sobór Watykański II: 1962-1965), w sposób szczególny zaś nauczenie Jana Pawła II, który stworzył teologiczno-filozoficzne podwaliny nowoczesnej katolickiej koncepcji sportu (Dziubiński 2008, s. 143-200).

W społeczeństwie polskim zachodzą wielopłaszczyznowe zmiany w sferze kultury, w tym kultury sportowej, jako że w ostatnim dziesięcioleciu znacznie zwiększyła się akceptacja dla wartości sportu powszechnego. W przeszłości, sięgając do tradycji Józefa Piłsudskiego, a później do tradycji państwa socjalistycznego, najważniejsze były wartości utylitarne aktywności sportowej, których realizacja polegała na przygotowaniu społeczeństwa do wykonywania obowiązków zawodowych i obrony ojczyzny. Dzisiaj tężyzna fizyczna nie odgrywa już tak ważnej roli w wykonywaniu obowiązków zawodowych, praca fizyczna stanowi bowiem margines aktywności zawodowej Polaków, a potencjał obronny kraju nie wynika wyłącznie ze sprawności fizycznej wojska, ale z dysponowania nowoczesnymi technologiami informatyczno-technicznymi i umiejętnościami ich wykorzystania podczas konfliktu (Dziubiński 2014a, s. 74-80).

Badania empiryczne dowodzą, że współczesne społeczeństwo polskie ceni wartości estetyczne, hedonistyczne i agonistyczne (Urych 2010). Podejmując aktywność sportową, chce te wartości realizować. Chce dbać o estetykę ciała zgodnie z obowiązującymi trendami w tym zakresie, chce czerpać przyjemność

2 Wypowiedź w stacji Orange Sport byłego prezesa PZPN Michała Listkiewicza, w której zwrócił uwagę na to, że w przeszłości ludzie biegający dla zdrowia byli traktowani przez znaczący odsetek społeczeństwa jako dziwacy. 
z uczestnictwa w ruchu, chce doświadczać pozytywnych przeżyć emocjonalnych związanych z rywalizacją sportową. Charakterystyczną cechą współczesnego uczestnika sportu powszechnego jest potrzeba przeżyć ekstremalnych, które zapewniają sporty nazywane właśnie ekstremalnymi lub adrenalinowymi. Często uczestnicy mówią: „Nie ma ryzyka, nie ma dobrej zabawy”, ale nie chodzi tu o ryzyko wedle kulturowej umowy, ale o prawdziwe ryzyko. Wspinanie się po górskiej ścianie z zabezpieczeniem jest przyjemne, jednak naprawdę atrakcyjne jest dopiero wspinanie się bez zabezpieczenia, kiedy każdy fałszywy ruch może spowodować odpadnięcie od ściany i zakończyć się śmiercią. Dążenie do maksymalizacji ryzyka i nieustanna pogoń za nowymi, mocniejszymi i jednocześnie, w ocenie uczestników, przyjemniejszymi doznaniami jest typową cechą społeczeństwa ponowoczesnego, którego fundamentem jest ciągle niezaspokojona wyrafinowana konsumpcja oraz nieustanna pogoń za coraz mocniejszymi przeżyciami. „Ciało ponowoczesne - pisze Zygmunt Bauman - jest przede wszystkim odbiorcą wrażeń. Spożywa ono i trawi przeżycia. Korzystając z przyrodzonej zdolności reagowania na podniety, jest narzędziem przyjemności”. I dodaje: „Utrzymywać ciało w stanie tak rozumianej sprawności, to odczuwać podniecenie na widok podniet i radości z ich konsumpcji. W sprawności ciała idzie nie tyle o to, do jakich wyczynów ciało jest zdolne, ile o to, jak głębokie są doznania przeżywane w toku ich dokonywania. Idzie głównie o wrażenia - które winny być pasjonujące, zachwycające, czarujące, ekstatyczne" (Bauman 1995, s. 90-91).

W społeczeństwach lepiej od naszego rozwiniętych występują podobne tendencje, ale realizujących te wartości jest znacznie więcej. Przyczyną takiego stanu rzeczy jest dłuższa tradycja tych społeczeństw w zakresie, po pierwsze, kultywowania wartości sportu oraz po drugie, dominacji racjonalnych idei, w których dbałość o estetykę ciała, czerpanie przyjemności o charakterze kinetycznym oraz potrzeba pozytywnych przeżyć emocjonalnych są bardziej ugruntowane w świadomości i zachowaniach obywateli (Dziubiński 2014b, s. 27-49).

W społeczeństwach zachodnich kultura jest tak zorganizowana, że niejako wymusza na członkach uczestnictwo w sporcie, a brak tego zaangażowania uruchamia system kontroli społecznej i w konsekwencji negatywne nieformalne sankcje społeczne w postaci zdziwienia, kpiny, werbalnej uszczypliwości itp. Zatem aktywność sportowa stanowi kulturową normę, natomiast jej brak traktowany jest jako odejście o tej normy, odchylenie od ustalonego porządku, a niekiedy jako dewiacja.

W naszym społeczeństwie kultura zaczyna posiadać coraz większą prosportową moc, uczestnicy sportu zaś coraz częściej spotykają się z gratyfikacjami symbolicznymi, takimi jak szacunek, uznanie i prestiż społeczny. Konsumpcja sportowa nabiera nobilitującej siły i teraz legitymizuje już przynależność do klas i warstw wyższych (Dziubiński 2013, s. 27-47). Uczestnictwo w aktywności ruchowej nie jest wyłącznie interpretowane w perspektywie korzyści zdrowotno-sprawnościowych, ale przede wszystkim w kategoriach symbolicznych. Jednym z pionierów zajmujących się problematyką konsumpcji był Max Weber, który twierdził, że konsumpcja w społeczeństwie nowoczesnym nie jest głównie środkiem, ale celem życia jednostek i zbiorowości (Weber 1984). Natomiast 
T. Veblen uważał, że celem konsumpcji („ostentacyjnej”) jest zamanifestowanie swojej pozycji społecznej i ukazanie ekonomicznej przewagi nad innymi (Veblen 1971). W społeczeństwie (po)nowoczesnym, zdaniem J. Baudrillarda, konsumpcja staje się aktem społecznym z szerokim spektrum znaków i symboli o ogromnej ważności społecznej. W konsumpcji przestaje się liczyć jej wymiar materialny, a jego pozycję zajmuje wymiar symboliczny (Baudrillard 1998). Właśnie takiego wymiaru nabrała konsumpcja sportowa, dzięki której jednostki i zbiorowości przydają sobie prestiżu społecznego lub odwrotnie, nie uczestnicząc w konsumpcji - pozbawiają się go.

Niezwykle istotną rolę w zmianie podejścia Polaków do sportu odegrało upowszechnienie się tzw. nowego paradygmatu zdrowia, który zastąpił dotychczas dominujący paradygmat biomedyczny (Maszczak 2014, s. 167-180). Zmiana ta polega na odejściu od pojmowania zdrowia w sensie negatywnym, tj. takim, w którym zdrowie rozumiane jest jako brak choroby i odnosi się wyłącznie do zaburzeń struktury i funkcji organizmu, na rzecz postrzegania zdrowia w sensie pozytywnym i powiązania go z jakością życia. Pojęcia charakteryzujące biomedyczny paradygmat zdrowia, takie jak choroba, szpital, leczenie, terapia, pacjent, zostały zastąpione w nowym paradygmacie zdrowia takimi pojęciami, jak zdrowie, profilaktyka, kontrola, opieka, osoba. W związku z tym ciężar odpowiedzialności za zdrowie został przeniesiony ze służby zdrowia i terapii farmakologiczno-medycznej na jednostkę i profilaktykę zdrowotną, której najlepszym orężem jest dostosowana do cech społeczno-demograficznych jednostki aktywność sportowa. Owa aktywność sportowa ma na celu potęgowanie zdrowia przez stosowanie ruchowych środków pielęgnacyjno-profilaktycznych (Rekowski 2011, s. 164-185). Tym samym zmiana dominującego paradygmatu zdrowia uczyniła z członków naszego społeczeństwa osoby suwerenne w wymiarze odpowiedzialności za swoje zdrowie i wpłynęła na ich zwiększony udział w aktywności sportowej.

\section{Podsumowanie}

Zmiana społeczno-kulturowa, która polegała na przejściu od społeczeństwa tradycyjnego do społeczeństwa industrialnego (nowoczesnego), związana była przede wszystkim z rewolucją naukowo-techniczną, masowymi migracjami ludności ze wsi do miast (ruchliwością przestrzenną), ruchliwością społeczną na merytokratycznych zasadach oraz kulturą masową (przekazywanie niezliczonej ilości informacji wielkiej rzeszy rozproszonych odbiorców) oraz globalizacją, czyniącą z naszego globu jedną wioskę na wzór wioski olimpijskiej. Próba ustalenia zależności między zmianą społeczną a współczesnym sportem powszechnym pozwala na stwierdzenie, że wszystkie zjawiska i procesy występujące w polskim społeczeństwie nowoczesnym są także obecne w większym lub mniejszym stopniu na gruncie sportu powszechnego. Oznacza to, że renesans uczestnictwa społeczeństwa polskiego w sporcie powszechnym jest przede wszystkim konsekwencją zmian w społeczeństwie i kulturze, które w wyniku kumulacji ilościowej 
doprowadziły do zmiany jakościowej, na którą zwracali uwagę, często w odmienny sposób, liczni przedstawiciele neoewolucjonizmu, tacy jak: A. White, H. Steward, M.D. Sahlins, G. Lensky czy T. Parsons.

Podstawowych przyczyn wzrostu uczestnictwa społeczeństwa polskiego w sporcie powszechnym należy zatem upatrywać w zmianach, jakie dokonały się w ostatnich latach w sferze społecznej i kulturowej. Do tych najistotniejszych zmian w sferze społecznej należy zaliczyć:

- skokowy wzrost odsetka osób z wyższym wykształceniem,

- statystyczny wzrost zamożności społeczeństwa,

- wzrost odsetka osób zatrudnionych w zawodach biurowych,

- migracje ludności z terenów wiejskich do miast,

- poprawę dostępności do sprzętu i infrastruktury sportowej.

Przedstawione zmiany w sferze społecznej bezpośrednio lub częściej pośrednio wpływają na aktywność sportową, ale połączone czy sprzężone niejako wywierają przemożny wpływ na zachowania Polaków w interesującej nas dziedzinie.

Niezwykle ważną rolę odgrywają też czynniki kulturowe, wśród których na plan pierwszy wysuwają się następujące:

- dominacja w społeczeństwie estetycznego i hedonistycznego wzoru kultury fizycznej,

- zwiększenie prestiżowej roli i znaczenia konsumpcji sportowej w konsumpcji kulturalnej społeczeństwa, uruchomienie się w społeczeństwie nieformalnej kontroli społecznej i związanych z nią sankcji pozytywnych względem osób uczestniczących w aktywności sportowej i negatywnych względem osób nieuczestniczących w aktywności sportowej,

- wzrost odsetka osób kierujących się prawdami racjonalnymi i empirycznymi, rezygnujących z interpretowania sukcesu ludzi w kategoriach determinizmu teologicznego lub biologicznego, na rzecz jednostkowego i zbiorowego działania ludzi, w tym także w zakresie zdrowia i sprawności fizycznej,

- wzrost odsetka osób uznających prawdę, że na zdrowie mają decydujący wpływ działania profilaktyczne i styl życia, a nie działania o charakterze szpitalno-farmakologicznym.

Przedstawione zmiany w sferze kulturowej mają ogromny bezpośredni lub bardziej pośredni wpływ na zachowania społeczeństwa w dziedzinie aktywności sportowej. Wpływ ten polega niejako na kulturowym przymusie symbolicznym, skłaniającym jednostki i zbiorowości do czynnego uczestnictwa w kulturze sportowej.

\section{Literatura}

Alexander J.C., The New Theoretical Movement, [w:] N.J. Smelser (ed.), Handbook of Sociology, Sage, Newbury Park 1988.

Baudrillard J., The Consumer Society: Myths and Structures, Sage Publications, London 1998. 
Bauman Z., Ponowoczesne przygody ciała, [w:] Z. Bauman, Ciało i przemoc w obliczu ponowoczesności, UMK, Toruń 1995.

Bell D., The Coming of Post-Industrial Society: A Venture in Social Forecasting, Basic Books, New York 1976.

Bennett T., Savage M., Silva E., Culture. Class. Distinction, Routledge, London-New York 2010.

CBOS (2008), Wyjazdy na wypoczynek, BS/177/2008.

CBOS (2010), Zainteresowanie sportami zimowymi w Polsce, BS/13/2010.

CBOS (2010), Czas wolny Polaków, BS/133/2010.

CBOS (2012), Polacy o swoim zdrowiu oraz prozdrowotnych zachowaniach i aktywnościach, $\mathrm{BS} / 110 / 2012$.

CBOS (2013), Aktywność fizyczna Polaków, BS/129/2013.

Czapiński J., Panek T., Diagnoza społeczna 2013. Warunki i jakość życia Polaków. Raport, Rada Monitoringu Społecznego, Warszawa 2013.Dimitrov D., Helmenstein C., Kleissner A., Moser B., Schindler J., Die makroökonomischen Effekte des Sports in Europa, Studie im Auftrag des Bundeskanzleramts, Sektion Sport, Wien 2006.

Dziubiński Z., Jana Pawła II wizja kultury fizycznej, [w:] Z. Dziubiński, Kościół rzymskokatolicki a kultura fizyczna, AWF, Warszawa 2008.

Dziubiński Z., Różnice i nierówności społeczne w sporcie, [w:] Z. Dziubiński, M. Lenartowicz (red.), Kultura fizyczna a różnice i nierówności społeczne, AWF/SALOS RP, Warszawa 2013.

Dziubiński Z., The Determinants of Polish Society's Participation in Sport and the Directions of Change, „Physical Culture and Sport. Studies and Research” 2014, No. 61.

Dziubiński Z., Zmiana społeczna jako faktor zmiany w sporcie, [w:] Z. Dziubiński, P. Rymarczyk (red.), Kultura fizyczna a zmiana społeczna, AWF/SALOS RP, Warszawa 2014.

Eurostat, Polski PKB na głowę czwarty od końca w UE, 2014, http://www.wykop.pl/link/1559375/ eurostat-polski-pkb-na-glowe-czwarty-od-konca-w-ue/ (dostęp: 15.02.2015).

Giddens A., Praca i życie gospodarcze, [w:] A. Giddens, Socjologia, PWN, Warszawa 2006.

Griswold W., Cultures and Societies in a Changing World, 4th ed., Pine Forge Press, Thousand Oaks, CA. 2012.

Halicki P., Stołeczny ratusz: generalnie mieszkańcy są zadowoleni z życia i usług, 2014,

http://wiadomosci.onet.pl/warszawa/stoleczny-ratusz-generalnie-mieszkancy-sa-zadowoleni-z-zyciai-uslug/0zk0n (dostęp: 15.02.2015).

MaratonyPolskie.pl, 2014,

http://www.maratonypolskie.pl/mp_index.php?dzial=3\&action=1\&grp=13\&trgr=1\&bieganie) (dostęp: 15.02.2015).

Maszczak T., Zdrowie jako wartość, [w:] T. Maszczak, Wychowanie przez rozwój. Edukacja, olimpizm, edukacja inkluzyjna, zdrowie, Fundacja CEO, Warszawa 2014.

Męka K., Zmiany w zakresie udziału Polaków w zajęciach rekreacyjnych oraz imprezach sportu powszechnego, [w:] Z. Dziubiński, P. Rymarczyk (red.), Kultura fizyczna a zmiana społeczna, AWF/ SALOS RP, Warszawa 2014.

Naisbitt J., Megatrends. Ten New Directions Transforming Our Lives, Warner Books, New York 1982.

Pareto V., Traktat o socjologii ogólnej, [w:] V. Pareto, Uczucia i działania. Fragmenty socjologiczne, PWN, Warszawa 1994.

Polska Biega. Raport-Narodowy Spis Biegaczy 2014, http://www.polskabiega.pl (dostęp: 15.02.2015).

Polska. Wybrane dane statystyczne, 2010, Urząd Statystyczny w Łodzi, http://old.stat.gov.pl/cps/rde/ xbcr/lodz/assets_czarnodruk_tom1_ludnosc_bael.pdf (dostęp: 15.02.2015).

Rekowski W., Zdrowie jako zjawisko społeczne, [w:] Z. Dziubiński, Z. Krawczyk (red.), Socjologia kultury fizycznej, AWF, Warszawa 2011.

Sorokin P.A., Social and Cultural Dynamics, t. 1-4, Harcourt Brace College Publishers, New York 1937.

Statistical Yearbook of the Republic of Poland, GUS, Warszawa 2012.

Szczepański M.A., Pokusy nowoczesności. Polskie dylematy rozwojowe, UŚ, Katowice 1992.

Sztompka P., Society in Action: The Theory of Social Becoming, Cambridge University Press, Cambridge 1991.

Sztompka P., Teorie zmiany społecznej, [w:] Encyklopedia socjologii, t. 4, Oficyna Naukowa, Warszawa 2002. 
Sztompka P., Socjologia. Analiza społeczeństwa, Znak, Kraków 2005.

Uczestnictwo Polaków w sporcie i rekreacji ruchowej w 2012 r., GUS, Warszawa 2012.

Urych I., Wzory i wartości kultury fizycznej w wybranych magazynach life-stylowych, praca doktorska, AWF, Warszawa 2010.

Tycner A., Bieg po pieniądze: wywiad z Z. Berdychowskim, „Do Rzeczy” 2014, nr 15.

Veblen T., Teoria klasy próżniaczej, PWN, Warszawa 1971.

Weber M., Szkice z socjologii religii, KiW, Warszawa 1984.

Wieliński B.T., Matusiak W., Polska równiejsza, „Gazeta Wyborcza” z dnia 15 września 2014 r.

Wyższe wykształcenie Polaków na tle Unii Europejskiej - statystyki, 2013, http://forsal.pl/artykuly/696706,wyzsze_wyksztalcenie_polakow_na_tle_unii_europejskiej_statystyki.html (dostęp: 15.02.2015). 